2nd International Conference Global Ethics -Key of Sustainability (GEKoS) | May 14, 2021 | Bucharest, Romania

\title{
Human Resources Management in Organizational Performance
}

\author{
Gabriel Ionuț VASILE, Xiaoyu ZHAN \\ https://doi.org/10.18662/lumproc/gekos2021/9
}

How to cite: Vasile, G. I, \& Zhan, X. (2021). Human Resources Management in Organizational Performance. In A. Grigorescu \& V. Radu (vol. ed.), Lumen Proceedings: Vol. 15. 2nd International Conference Global Ethics Key of Sustainability (GEKoS) (pp. 102-112). Iasi, Romania: LUMEN Publishing House. https://doi.org/10.18662/lumproc/gekos2021/9 
Gabriel Ionuț VASILE et al.| Lumen Proceedings 15 | GEKoS 2021

\title{
Human Resources Management in Organizational Performance
}

\author{
Gabriel Ionut, VASILE1', Xiaoyu ZHAN²
}

\begin{abstract}
The world we live in has countless organizations that are born, grow or disappear. The use of buman resources is very common and essential for all types of organizations at all times. They ensure the survival and tryingness of the organization in today's dynamic business environment. The investment in human resources means not only the regular salary payments but also employees' personal and professional development in order to enhance their job skills and act responsibly when necessary. The traditional approach to human resources management implies only the costs for the job performed. The unique values of human resources imply both the ability of personal and professional development and the desire of self-improvement as standards of the modern world require.

Work evaluation can have a negative impact and that happens when the manager considers the employee, as individual, accountable for bad job performance and does not take an account of the weak areas of performance evaluation and control.
\end{abstract}

Keywords: organization, performance, buman resources, evaluation.

1 PhD student, "Valahia" University of Targoviste, Doctoral School of Economics and Humanities, Lt. Stancu Ion street, Nr. 35, Targoviste, Romania, ionutvasile2020@yahoo.com

$2 \mathrm{PhD}$ student, "Valahia" University of Targoviste, Doctoral School of Economics and Humanities, Lt. Stancu Ion street, Nr. 35, Targoviste, Romania, xiao@,xiao.ro 


\section{Introduction}

When asked about human resource management policies within organizations, most managers will tend to respond that their company has implemented such policies. Nevertheless, when trying to describe their nature and content, they encounter great difficulties. It is generally assumed that people with managerial responsibilities are expected to acknowledge them even though these policies are not always available in written format.

In the organizations with trade unions established, the human resource management responsibilities are always included in various clauses of the collective employment agreement. These clauses cover important issues pertaining to human resources management: employment, training, promotion, fair and equal treatment of persons (Bartels \& Weiss, 2019).

Presenting such unwritten policies associated to already existing regulation is not enough to ensure uniform criteria intended to serve the decision-making process in the field of efficient and effective use of human resources. Therefore, without becoming excessively formal and having no intention to encourage bureaucracy, it is recommended to write down and disseminate the policy of the human resource management (Căprărescu, 2008).

The human resource management policy reflects the intentions, skills and objectives of the management in terms of identifying, retaining and developing human resources. It is the expression of the objectives pursued and the means used to this end. It is also an orientation and action guide to all persons taking managerial accountability (Paraschiv Ganea \& Hubel Anghel, 2020).

After consulting with their collaborators who have to collect and process information of various nature, the managers in charge elaborate the human resource management policies (Stegăroiu et al., 2020). The information received from such collaborators relates to issues encountered by higher management when taking on new employees, when making decisions with regards to working teams, when making decisions on their employees' professional training or their promotion opportunities; issues regarding grievances filed by the employees when they consider themselves deprived of a fair and equal treatment; issues on the results of some investigations conducted in relation to satisfaction / dissatisfaction with work conditions within the organization; claims of the employees, with precise delineation between what may be discussed at the negotiation table and what falls under the subject matter of the policies (Petrescu \& Manghiuc, 2020). 


\section{Motivating human resources, prerequisite for performance of the organization}

At present, motivation is a popular term in organizations. The complexity of the concept makes a simple, unanimously accepted definition difficult to identify. A satisfactory answer to the question "what makes employees work efficiently?” is still being pursued (Tăbîrcă et al., 2019). The difficulty comes from the fact that any researcher has to make some assumptions as to the causes of the behavior observed or written down. Consequently, there will always be a certain subjective component in all and motivation-related reasoning. Nevertheless, we can opt for the following definition: "the motivation is a psychological and physiological change internally experienced by the human being whenever a need occurs; to meet this need the individual adopts a behavior aiming to regain a psychological and physiological balance" (Cindrea, 2008).

One of the main activities in human resource management is motivation, also seen as basis in exercising the driving function, one of the functions of the management processes, alongside forecast, coordination and control-assessment.

Materialized in correlating needs, aspirations and interests of the human resources within the organization with reaching goals and exercising tasks, motivation plays several roles (Morosan-Danila et al., 2020):

The managerial role is the most direct and consists mainly in identifying the content and the effectiveness of the driving function, which, in turn, decisively conditions all the other managerial functions - forecast, organization, coordination and control-assessment (Ştefan et al., 2009).

On a different level, motivation generates a substantial impact on the characteristics and functionality of the entire managerial system of the organization (Croitoru et al., 2012). Quality of the decisions, operationalization of the methods, managerial techniques and procedures and general effects, accuracy and flexibility of the informational subsystem as well as the functionality of the organizational methods in an organization - namely the key elements of the managerial system - are directly conditioned upon motivating the personnel.

The organizational role refers to the major impact that motivation has, both directly and through other managerial elements, on the way the organization and its performances function. Given that motivation drives employees' skills, know-how and energy, in other words the most important resource of the an organization, which is also a mobilizing factor for the other resources, its effects at organizational level are highly powerful. The content and the motivation methods used in an organization contribute to 
the imprinting of some traits upon its organizational culture (Grigorescu et al., 2020).

The individual role refers to the strong dependence of satisfactions and dissatisfactions of each employee within an organization, their evolution, the motivation coming from the organization. The more intense the motivation is, motivation based on consideration of needs, aspirations and expectations of the employees, on the one hand, and their potential and effort made in line with interests, goals and requirements of the organization, on the other hand, the more satisfied the personnel is. Furthermore, they make better use of their skills and grow more rapidly and intensely (Cole, 2000).

The economic role aims at the indirect yet considerable conditionality of the economic performances of each country upon the motivation that is predominant in companies and other organizations operating nationwide. When motivation is deficient in an organization, the economic results of the organization fail to reach to the level required and therefore - they reflect negatively on the overall performances of the country in question (Petrescu \& Manghiuc, 2020).

The social role represents in fact the synergic effect of the previous roles at the level of the psycho-sociological elements that characterize the population of a country. The social climate in a country, the social relations are determined to a significant extent by the multiple mostly indirect and propagated effects of the motivation that prevails within companies, authorities, and other organizations where people carry out their activities.

Depending on the specific needs and the international, national, and organizational context in which they work, every person has aspirations and a set of motivational expectations. Results of some conscious and unconscious processes, motivational aspirations are motivational palliatives of which achievement represents goals in terms of meeting personal needs. The expectations are "adjusted" aspirations depending on the organizational conditions existing at national and international level. In other words, expectations represent aspirations achievable under the given conditions and influenced by the ensemble of the organizational and contextual variables (Grigoras-Ichim \& Morosan-Danila, 2020).

The aspirations and expectations explicitly reflect in the actions, efforts, decisions and behavior of the employee. Typically, the aspirations and expectations do not fully reflect in skills, efforts, behaviors, etc. What interfere are firstly the personal limits set by the parameters of the individual variables of each employee and secondly, the favorable and/or restrictive influence of the organizational and contextual variables (Ion, 2020). 
In order to be successful at both individual and organizational level it is essential to identify the best alignment possible between individual aspirations and expectations and objectives, tasks and other organizational elements, on the one hand, and personal efforts and decisions, actions and behaviors, on the other hand (Bustin, 2014). Individual performance refers to those results of the employee based on personal efforts and knowledge that match their aspirations, objectives, and tasks. Organizational performance considers conducting organizational activities and reaching the goals of the organization due to the direct or indirect contribution of the employee (Partenie, 2009).

Depending on the results and the individual and organizational performances, the employees are rewarded or sanctioned. It is essential to correlate rewards and sanctions with performances, mostly, but also with skills, efforts, actions, decisions, and behaviors of the employees (Vasciuc, 2020). When the level of such correlation is high, the employees' economic, cognitive and relational needs are largely met. Consequently, there is motivational effect, there is strong motivation among the employees who will continue to work harder and better (14 Iurian \& Radu, 2020). In this way, competitive organizational performances are in time generated and perpetuated. Another major effect of strong motivation is the impetus towards professional growth of the employees (Abrudan, 2007). The cognitive and relational needs are frequently enhanced compared to previous timeframes, and new needs come to surface. The employees are thereby ensured further "motivational energy", with multiple positive effects at individual, organizational and national level (Abrudan et al., 2010).

The motivational cycle is defined as the entirety of the needs, aspirations, expectations, skills, efforts, decisions, actions, and behaviors correlated with the individual and organizational performances and the motivations used, structured and particularized under the influence of the individual, organizational and contextual variables involved (Nicolescu \& Verboncu, 2008).

\section{Strategies relating to employees' accountability to increase performances}

The accountability is one of the fundamental, crucial, and dynamic factors influencing the success of an organization (Schlenker, 1997). It means "clear commitments which were carried through" (Evans, 2008). Accountability means that the employees may rely on one another towards performance-related commitments (Petrovici, 2007). An employee should 
take personal responsibility for actual results. The choices, behaviors and actions of the employee influence the result of the performance. Resultbased accountability generates better relations among employees and improves work satisfaction and performance (Evans, 2008). Determination is an intellectual component of the accountability. This means that the employee must use their skills in order to get the desired outcome at work.

The employees' accountability strategy may be implemented as follows:

1. Employee empowerment method refers to encouraging employees' initiative and autonomy so that they may take control of their tasks. The goal is to motivate the employees towards innovation as to face up to challenges encountered in carrying out tasks assigned and in implementing their projects. It is about assessing contributions, stimulating creativity and encouraging awareness of the importance of personal initiative.

The technological advances, mainly due to automation of repetitive tasks and increasingly higher digitalization of processes, enabled new forms of work occurred because of the geographical constraints. Many employees work from a distance. To support this development, the organizations were pushed to explore new forms of work organization focused more on an autonomous employee who becomes therefore empowered. This is how the company becomes high-performing and manages to optimize their resources with the support of their committed employees (Trel'ová, \& Olšavský, 2017).

2. Employee development method involves a global approach that requires the support of the entire organization. The researchers conducted indicate that the salary is not the main source of motivation even though it continues to be an important element. "It is mistakenly considered that an increase in salary or a bonus alone will motivate the employee on a long term. The effect of an increased salary on motivation lasts two to three weeks only" (Sari et al., 2021).

A corporative culture as well as customized training programs and talent management are also required. This includes development of interpersonal abilities, emotional intelligence, and involvement (MorosanDanila et al., 2020).

Employee development offers a definite competitive advantage to the organization and represents economic benefit to the same degree as innovation and productivity do. Nonetheless, the organization must comply with certain rules, the most important of which being the combination of efforts and not neglecting the essential role of the human resource manager. 


\section{Getting employees involved in the decision-making process}

is another method used to turn employee accountability strategy into good account.

The people represent the solid ground of all and any organization. Their employees are a source of knowledge and ideas, resource which is most times unexplored. Getting employees involved in the decision-making process empowers them to contribute to the success of an organization, on the one hand, and saves the company time and money for higher productivity and low outsourcing (13 Iurian \& Radu, 2020).

By actively involving the employees in the decision-making process, the managers of the organization make a statement on the value of their employees. When involved in setting and reaching organizational and departmental goals, the employees naturally develop more profound commitments as to such goals and make contributions and decisions that are useful in reaching success(Petrescu \& Manghiuc, 2020).

Furthermore, the customers also benefit whenever organizations encourage them to contribute. The employees who interact directly with customers often have more information on the challenges faced by customers and their feedback. When managers make all the decisions on their own, with no contribution coming from the employees, their ideas are limited to their past perception and experiences (Nicolescu \& Verboncu, 2008).

Using employees in the decision-making process rather than outsourcing some activities saves financial resources and time. Moreover, it provides the company with reliable long-term support from those who know the corporation the best (Yeo \& Lai, 2020).

In addition, the employees' involvement is a good way to collect information on the employees regarding how they work in a specific working environment and where training may be required. All these increase efficacies and eventually lead to better teamwork and higher performances.

Most employees value the opportunity to contribute to the decision-making process and to experience the feeling that you have the chance to get involved. Efficient communication is vital to the process. The organizations use a series of mechanisms to promote involvement and participation of the employees, such as employee survey, suggestion scheme, meetings, partnership committees and works councils (Nicolescu \& Verboncu, 2008). 


\section{Conclusions}

We consider that, at organizational management level, one of the main objectives to progress is continuous performance of the employees and their permanent motivation. The basic condition to reach excellence in business is awareness of the role and the importance of human resources and adoption of the most suitable strategies to motivate employees to capitalize their professional potential best.

To be successful, the organization has to know how to use the potential of their employees, being at the same time aware that each employee can do better than they think. This is the very role of the management - to emphasize their qualities and minimize their weaknesses. Under these circumstances, one should consider two fundamental aspects, employee motivation and methods to consolidate and stimulate motivation for good work. These two aspects obviously lead to best results. However, motivations are evidently different from one employee to another, depending on their needs, personalities, or leading values. This explains why we believe that to use a single generally valid model on all employees is not beneficial.

The inventory of the needs that an employee (individual) pursues has been an issue widely debated by many authors in the literature. For the MSP model, we have extracted the same needs as Maslow's. According to him, the individual pursues all their life to satisfy five categories of needs (physiological, security, social, esteem and self-actualization). When a category of needs has been fully satisfied, a new one emerges.

Following analysis of the needs illustrated in our model, we have pinpointed the following three aspects:

$\checkmark$ The employees' behavior is influenced by the need that they experience at a given time as being the most intense.

$\checkmark$ Once the need has been satisfied, it no longer motivates in a similar manner.

Based on the analysis of the needs below, one may see the transition from "to be" to "to have" approach: while the physiological needs are satisfied in terms of "being" (hungry, thirsty, or sleepy), the transition is towards the social needs in terms of developing and "having": esteem, appreciation, recognition. Taking into consideration the self-actualization needs, they share the same level as the social needs, at a more collective than individual dimension: our desire is to organize, serve, create, invent, and exist.

Every time organization leaders are successful in getting to know their employees, their preoccupations, aptitudes, aspirations, and interests, they secure a favorable work climate, assign jobs available in a rational manner, form work teams in a judicious way, choose the best managers and create the framework for rewards and promotions. According to the MSP 
Gabriel Ionuţ VASILE et al.| Lumen Proceedings 15 | GEKoS 2021

model, all these entail an increase in the degree of satisfaction of the work teams.

\section{References}

Abrudan, D. (2007). Motivarea, evaluarea performanțelor şi recompensarea resurselor umane. [Motivation, Assessing Performances and Rewarding Human Resources]. Solness.

Abrudan, M., Deaconu, A., Lukacs, E. (2010). Echitate şi discriminare în managementul resurselor umane. [Equity and Discrimination in Human Resource Management]. Publishing House of School of Economics.

Bartels, A., \& Weiss P. (2019). Performance effects of privatisation: an empirical analysis of telecommunication companies in Germany and Romania. HOLISTICA - Journal of Business and Public Administration, 10(2), 7-22. https://doi.org/10.2478/hjbpa-2019-0012

Bustin, G. (2014). Accountability: The Key to Driving a High-Performance Culture. McGraw-Hill

Căprărescu, G. (2008). Managementul resurselor umane [Human Resource Management]. Prouniversitaria Publisher.

Cindrea, I. (2008). Managementul resurselor umane [Human Resource Management]. "Lucian Blaga" University Publishing House.

Cole, G. A. (2000). Managementul personalului [Personnel Management]. Codecs Publishing House.

Croitoru, G., Radu, F., Nitu, O., \& Tileaga, C. (2012). Ways to Increase the Efficiency of Recruitment, Selection and Employment Strategies in Large Organizations from Dambovita County. Risk in Contemporary Economy. 219224.https://EconPapers.repec.org/RePEc:ddj:fserec:y:2012:p:219-224

Evans, H. J. (2008). Winning with Accountability: The Secret Language of High-Performing Organizations. Corner Stone Leadership Institute.

Grigoras-Ichim, C.-E., \& Morosan-Danila, L. (2020). Analysis of the Correlation Managerial Decisions -Interim Financial Statements. In A. Grigorescu \& V. Radu (vol. ed.), Lumen Proceedings: Vol. 11. 1st International Conference Global Ethics -Key of Sustainability (GEKoS) (pp. 203-211). Iasi, Romania: LUMEN Publishing House. https://doi.org/10.18662/lumproc/gekos2020/21 Grigorescu, A., Lincaru, C., \& Pîrciog, S. (2020). Ethic Leadership Trigger for Talents. In A. Grigorescu \& V. Radu (vol. ed.), Lumen Proceedings: Vol. 11. 
Gabriel Ionuț VASILE et al.| Lumen Proceedings 15 | GEKoS 2021

1st International Conference Global Ethics -Key of Sustainability (GEKoS) (pp. 3244). Iasi, Romania: LUMEN Publishing House.

https://doi.org/10.18662/lumproc/gekos2020/05

Ion, A. E. (2020). Ethics and Sustainability in Small and Medium-Sized Enterprises Public Policies. In A. Grigorescu \& V. Radu (vol. ed.), Lumen Proceedings: $V$ ol. 11. 1st International Conference Global Ethics -Key of Sustainability (GEKoS) (pp. 74-85). Iasi, Romania:LUMEN Publishing House. https://doi.org/10.18662/lumproc/gekos2020/09

Iurian, S., \& Radu, F. (2020). The Impact of International Migration on Entrepreneurship. In M. W. Staniewski, V. Vasile, \& A. Grigorescu (vol. ed.), Lumen Proceedings: Vol. 14. International Conference Innovative Business Management \& Global Entrepreneurship (IBMAGE 2020) (pp. 326-335). Iasi, Romania: LUMEN Publishing House. https://doi.org/10.18662/lumproc/ibmage2020/24

Morosan-Danila, L., Nastase, C.-E., \& Grigoras-Ichim, C.-E. (2020). The Link Between Employees' Motivation With Organisation's Performance. In A. Grigorescu \& V. Radu (vol. ed.), Lumen Proceedings: Vol. 11. 1st International Conference Global Ethics -Key of Sustainability (GEKoS) (pp. 264-272). Iasi, Romania: LUMEN Publishing House.

https://doi.org/10.18662/lumproc/gekos2020/27

Nicolescu, O., \& Verboncu, I. (2008). Fundamentele managementului organizației [Fundamentals of organization management]. Universitară Publishing House.

Paraschiv (Ganea), G.I., \& Hubel (Anghel), S.-R. (2020). The Role of Public Policies and Economic Instruments in Stimulating the Circular Economy. In A. Grigorescu \& V. Radu (vol. ed.), Lumen Proceedings: Vol. 11. 1st International Conference Global Ethics -Key of Sustainability (GEKoS) (pp. 283294). Iasi, Romania: LUMEN Publishing House. https://doi.org/10.18662/lumproc/gekos2020/29

Partenie, A. (2009). Managementul Resurselor Umane [Human Resource Management]. Eurobit Publisher.

Petrescu, C., \& Manghiuc, I. (2020). Mobbing at Work and the Impact of Employee Performance. In A. Grigorescu \& V. Radu (vol. ed.), Lumen Proceedings: Vol. 11. 1st International Conference Global Ethics -Key of Sustainability (GEKoS) (pp. 273-282). Iasi, Romania: LUMEN Publishing House. https://doi.org/10.18662/lumproc/gekos2020/28 
Petrovici, V. (2007). Managementul resurselor umane [Human Resource Management] (4th ed.). Muntenia Publisher.

Sari, W., Sari, P., \& Aktrisa, R. (2021). The Impact Work Family Conflict on Performance: The Case of Married Female Nurses. HOLISTICA - Journal of Business and Public Administration, 12(1), 11-26. https://doi.org/10.2478/hjbpa-2021-0002

Schlenker, B. R. (1997). Personal Responsibility. Applications of the Triangle Model. In L. Cummings \& B. Staw (Eds.), Research in Organizational Behavior (pp. 241-301). JAI Press.

Ştefan, V., Fratila, C., Radu, F. (2009, September 24). Development of modern technologies in management. International Conference „Management Horizons”. Vytauto Didziojo universitas „Taikomoji ekonomika”, Kaunas, Lithuania.

Stegăroiu, I., Radu, V., Simsek, H., \& Tăbîrcă, A.I. (2020). Impact of Leadership Team Values and Performance on Organizational Behavior. In I. Panagoreț \& G. Gorghiu (vol. ed.), Lumen Proceedings: Vol. 10. International Conference Globalization, Innovation and Development. Trends and Prospects (G.I.D.T.P.) (pp. 241-251). Iasi, Romania: LUMEN Publishing House. https://doi.org/10.18662/lumproc/gidtp2018/27

Tăbîrcă, A. I., Ivan, O. R., Radu, F., \& Djaouahdou, R. (2019). Qualitative Research in WoS of the Link between Corporate Social Responsibility and Corporate Financial Performance. Valahian Journal of Economic Studies, 10(1), 107-118. https://doi.org/10.2478/vjes-2019-0011

Trel’ová, S., \& Olšavský, F. (2017). Employee Satisfaction with Training Opportunities and its Relation to Internal Marketing. HOLISTICAJournal of Business and Public Administration, 8(2), 7-16. https://doi.org/10.1515/hjbpa-2017-0009

Vasciuc, C. (2020). Reflection on Personal Development, Facts and Rules to be Applied in the Management of Companies. HOLISTICA - Journal of Business and Public Administration, 11(2), 140-150. https://doi.org/10.2478/hjbpa-2020-0024

Yeo, A., \& Lai, M. (2020). The Influence of B2B Relationship Quality on Opportunism and Firm Performance. HOLISTIC A - Journal of Business and Public Administration, 11(3), 59-87. https://doi.org/10.2478/hibpa-2020$\underline{0032}$ 